\title{
Vulvar Basal Cell Carcinoma of a 40 Years Old Black Woman: About a Case and Literature Review
}

\author{
Gninlgninrin Apollinaire Horo, Kacou Edele Aka, Abdoul Koffi, Konan Séni, B. Effi, \\ Koné Mamourou \\ Gynaecology Obstetrics Department, Teaching Hospital of Yopougon, Abidjan, Côte d'Ivoire \\ Email: apollinaire.horo@univ-fhb.edu.ci, edelpap@gmail.com, kkoffiabdoul@yahoo.fr, senikonan@yahoo.fr, \\ mamourouk@hotmail.com
}

Received 24 May 2016; accepted 19 August 2016; published 22 August 2016

Copyright (C) 2016 by authors and Scientific Research Publishing Inc.

This work is licensed under the Creative Commons Attribution International License (CC BY).

http://creativecommons.org/licenses/by/4.0/

cC) (†) Open Access

\begin{abstract}
Vulva Basal Cell Carcinoma (BCC) is a rare tumor. It usually occurs in Caucasians at an advanced age. We present a case of vulvar BCC in an African patient under 40 years old with HIV infection successfully treated surgically. This presentation is exceptional because of age, race, and the immune status of the patient.
\end{abstract}

Keywords

Basal Cell Carcinoma, Vulva, Cancer, Africa Woman, Young Adult

\section{Introduction}

Basal cell carcinoma (BCC) is the most common human malignancy. Its incidence increases with age and among white women. It is observed in most cases (85\%) in areas exposed to sunlight, such as head and neck. But there are atypical sites such as the vulva, armpit, perianal and genital areas that are not exposed to sunlight. Vulvar location represents approximately $1 \%$ of all BCC and less than 5\% of all cancers of the vulva [1] [2]. The etiology is unknown but for vulvar BCC risk factors have been implicated. These factors that predispose to these gene mutations include advanced age, exposure to ionizing radiation, and chemicals (such as arsenic) inherited and chronic inflammation [3]. Clinical symptoms vary; however it is mainly in the form of vulvar nodule and vulvar pruritus [1]. The diagnosis is essentially histological. We report a case of vulvar BCC in an African patient under 40 years old with HIV infection successfully treated surgically after obtaining his written and informed consent. This presentation is exceptional because of age, race, and immune status of the patient.

How to cite this paper: Horo, G.A., Aka, K.E., Koffi, A., Séni, K., Effi, B. and Mamourou, K. (2016) Vulvar Basal Cell Carcinoma of a 40 Years Old Black Woman: About a Case and Literature Review. Open Journal of Obstetrics and Gynecology, 6, $553-$ 557. http://dx.doi.org/10.4236/ojog.2016.69071 


\section{Case Report}

A 38 years old woman consulted for a vulvar ulceration. The symptomatology started by the occurrence of a right unilateral mass of vulgar painless farm nonpruritic appeared there's 2 years. This mass was treated locally with unidentified herbal products and earth without success. It follows ulceration. There is no prior history of radiation therapy, tanning, or family history of skin cancer and skin depigmentation. The patient was HIV 1 under hight active antiretroviral (HAART) since 06 years and has changed its treatment 3 years ago after virologic failure. Physical examination revealed an ulcerated area of about $20 \mathrm{~mm}$ of major axis to the upper third of the large right labium majus (Figure 1, Figure 2). The remainder of the genital and pelvic exam is normal. An excisional biopsy of the area was performed. Histopathological examination revealed a multilobular tumor of the epidermis, consisting of basaloid epithelial cells, making evoke basal cell carcinoma. She undergo a radical vulvectomy. The final histologic result is a proliferation of cells identical to cells of basal layer. These cells forming masses appendues to the epidermis or digging into the dermis and adopting a palisading arrangement at their periphery. Some lobules exhibit keratinization homes. On the surface there are outbreaks of ulceration associated with inflammation. The surgical margins are healthy more than one $\mathrm{cm}$ (Figure 3). The patient after 12 months of follow-up shows no vulvar dermatologic lesion (Figure 4).

\section{Discussion}

Approximately 250 cases of vulvar BCC have been reported in the literature [2]. Most epidemiological studies involve ultraviolet rays as the main source for the BCC areas exposed to the sun. The etiology is unknown but for vulvar BCC risk factors have been implicated. Millar et al. [4] have identified immunosuppression caused by aging, chronic vulvovaginitis, radiotherapy and hormonal changes as factors that could significantly influence the basal cell degeneration leading to carcinoma. Barrett [3] noted the importance of mutations of the p53 gene in the pathogenesis of BCC in about $50 \%$ of cases; these factors that predispose to these gene mutations include advanced age, exposure to ionizing radiation, and chemicals (such as arsenic) inherited and chronic
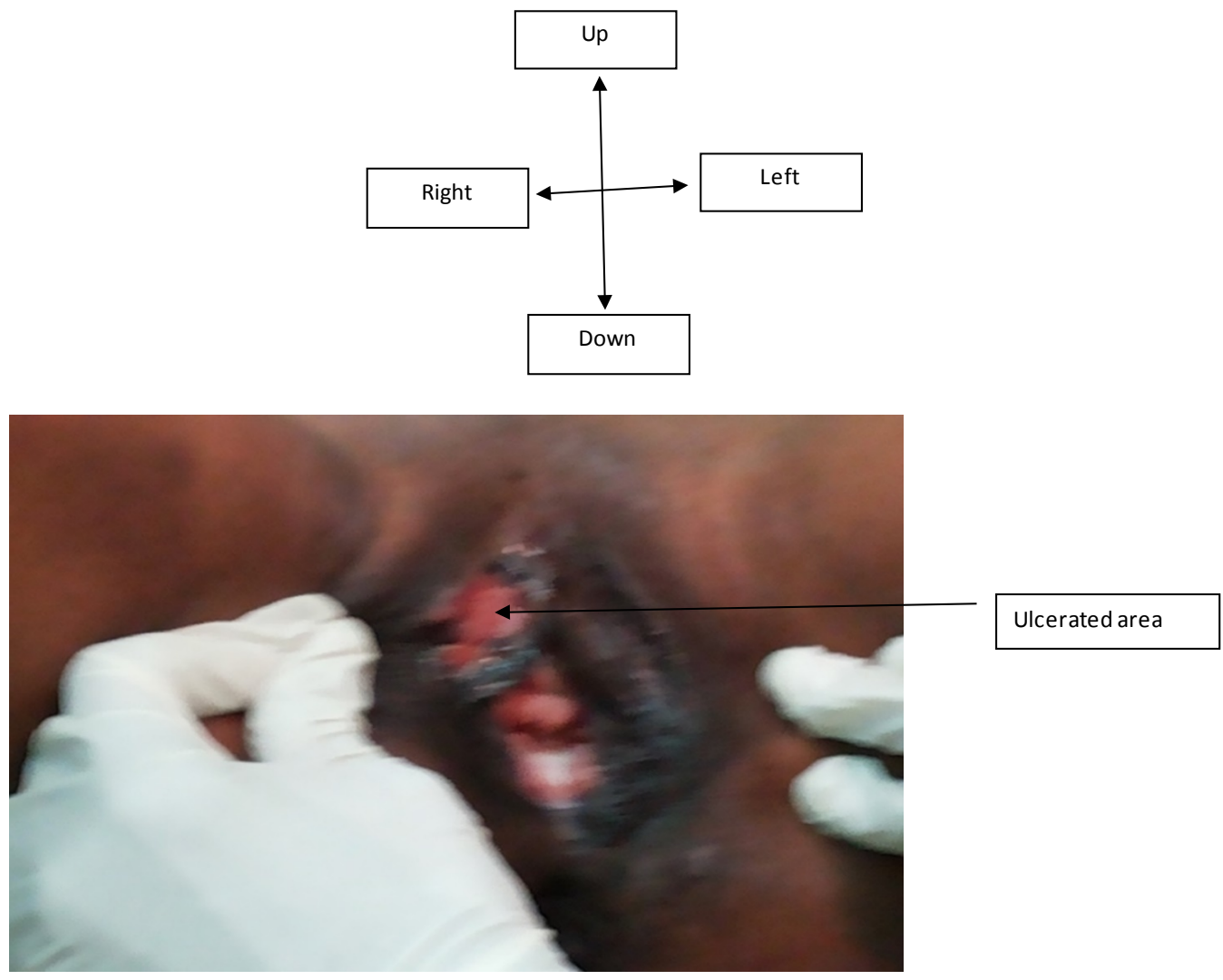

Figure 1. Vulvar ulceration about $1.5 \mathrm{~cm}$ in diameter to the upper third of the large right labium majus. 

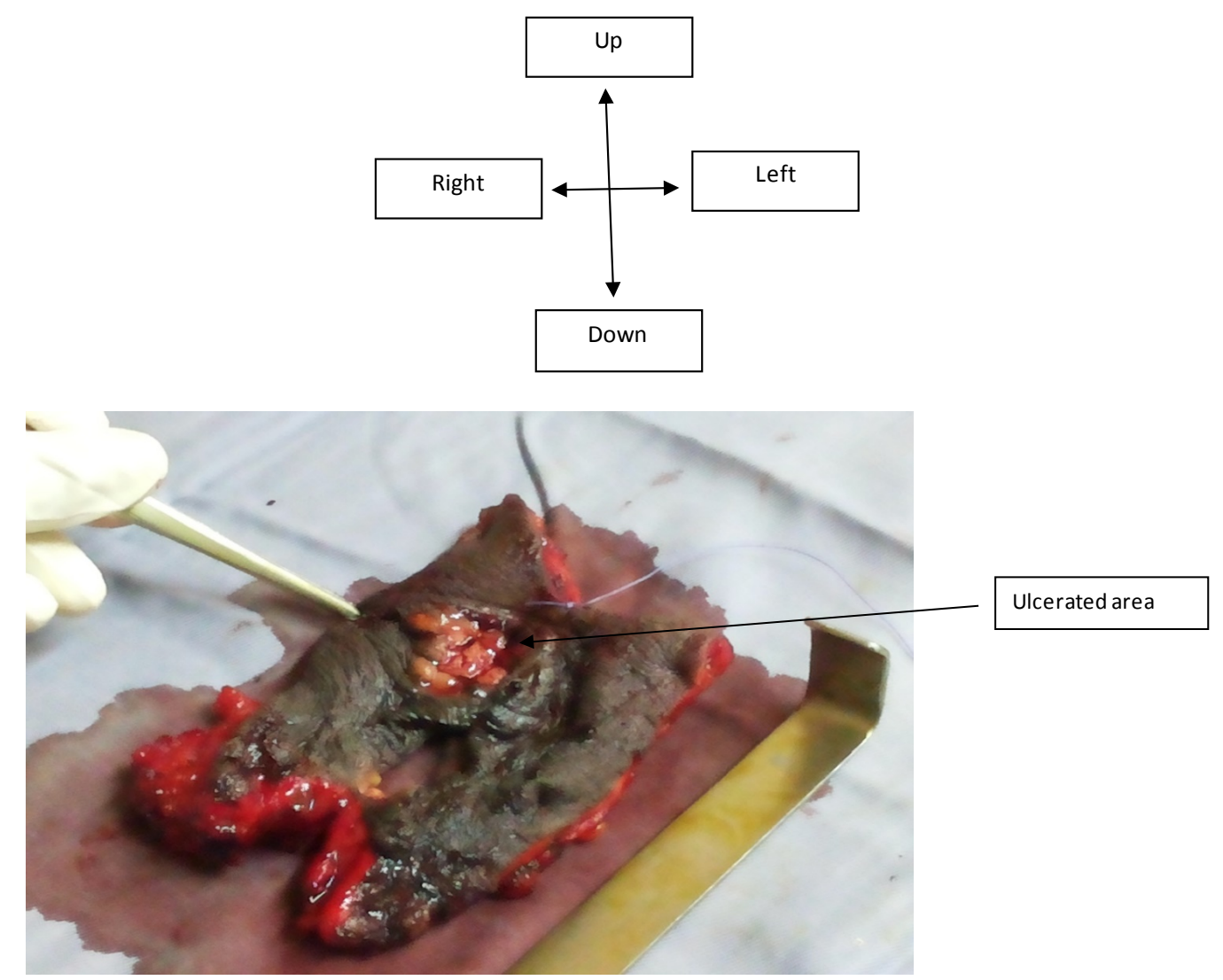

Figure 2. Excised tissue of radical vulvectomy with the ulcerated area.
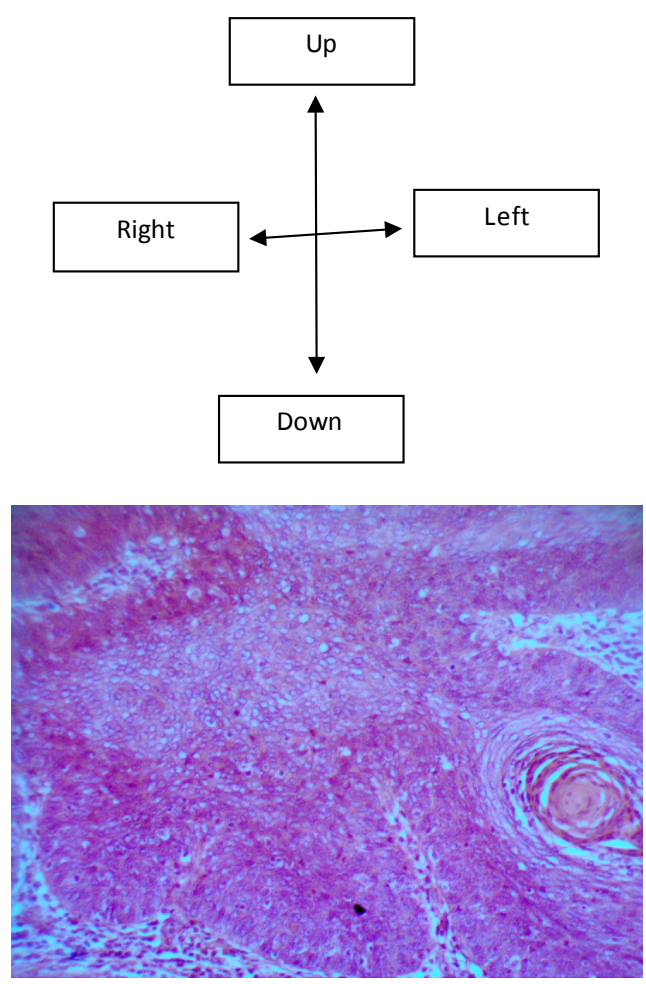

Figure 3. Squamous-cell keratinizing epithélioma $(\times 20)$. 

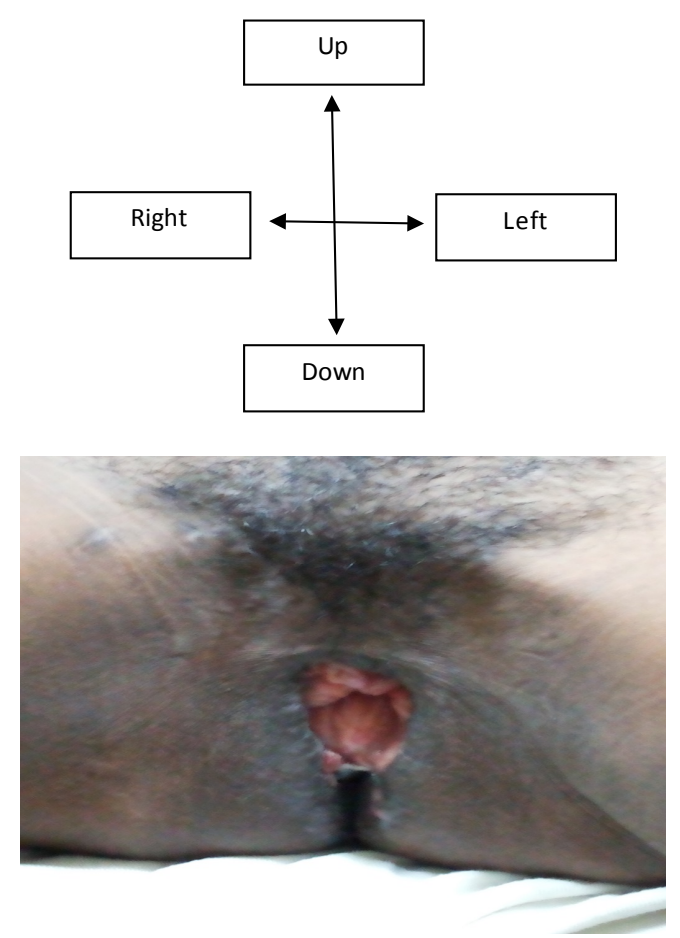

Figure 4. Perineum scar 6 months later.

inflammation. Gibson and Ahmed [5] after examining a series perianal and genital lesions of BCC have selected two main mechanisms that are age and local trauma in this region. Our patient under HAART since 6 years changed his treatment there is 03 years after a virological failure which could trigger a cellular process responsible for his condition. Indeed, few studies have been done to show a relationship between HIV and BCC. Eliezri [6] found no relationship with infection by the human papillomavirus (HPV).

Vulvar BCC are discovered at an advanced age averaged 70 years [1] [2] [7]. In our case, the vulvar BCC occured before 40 years. This late discovery can be due to low public awareness which should immediately consult the doctor for any vulvar lesion. Clinical symptoms of vulvar BCC are variable. The main presentations are vulvar pruritus (35\%), nodule (30\%), bleeding (25\%) and pain (18\%). It is sometimes asymptomatic [1]. It occurs most commonly on the labia as a plate eroded hyperpigmented [8]. In our case, patient complained of a nodule for two years followed by ulceration. The diagnosis would have been made earlier if it underwent a biopsy Levy at the stage of the nodule with possibility of conservative treatment.

This is a locally invasive slow growing tumor, but limited in the dermis, which allows definitive surgical treatment with a lumpectomy or destruction [7] [9]. However, local recurrence is observed up to 20\% of cases due to insufficient resection [1] [2] [7]. Metastatic disease is rare, on the order of 0.1\% [7]. Lymph node metastases are most frequently observed requiring inguinal lymphadenectomy in treatment. Other metastatic sites have been described by Suarez-Amor [9] namely bone, lungs and skin. The risk of metastasis increased in aggressive histological subtypes (of morpheaform, infiltrative basosquamous), and a large tumor size ( $>2 \mathrm{~cm}$ ) [9] [10]. The local excision must be done with clear margins pathologically proven $1 \mathrm{~cm}$ [2] [7]. Regarding our patient, the size of the tumor is less than $2 \mathrm{~cm}$ and under non agressive histological type. She has undergone a complete and wide excision without inguinal lymphadenectomy with histologic control of the margins. Faced with the risk of local recurrence and association with other cancers in these elderly patients, prolonged monitoring is necessary.

\section{Conclusion}

BCC is a rare skin vulvar cancer with an insidious and non-specific behavior. Any persistent chronic lesion in the vulvar region, at any age, should be given a histological examination. Early detection is essential to allow complete surgical cure and long-term monitoring is necessary. 


\section{References}

[1] De Giorgi, V., Salvini, C., Massi, D., Raspollini, M.R. and Carli, P. (2005) Vulvar Basal Cell Carcinoma: Retrospective Study and Review of Literature. Gynecologic Oncology, 97, 192-194. http://dx.doi.org/10.1016/j.ygyno.2004.12.008

[2] Pisani, C., Poggiali, S. and De Padova, L. (2006) Basal Cell Carcinoma of the Vulva. Journal of the European Academy of Dermatology and Venereology, 20, 446-448. http://dx.doi.org/10.1111/j.1468-3083.2006.01456.x

[3] Barrett, T.L., Smith, K.J., Hodge, J.J., Butler, R., Hall, F.W. and Skelton, H.G. (1997) Immunohistochemical Nuclear Staining for p53, PCNA, and Ki-67 in Different Histologic Variants of Basal Cell Carcinoma. Journal of the American Academy of Dermatology, 37, 430-437. http://dx.doi.org/10.1016/S0190-9622(97)70145-2

[4] Millar, S. (1991) Biology of Basal Cell Carcinoma. Journal of the American Academy of Dermatology, 24, 1-9. http://dx.doi.org/10.1016/0190-9622(91)70001-I

[5] Gibson, G.E. and Ahmed, I. (2001) Perianal and Genital Basal Cell Carcinoma: A Clinicopathologic Review of 51 Cases. Journal of the American Academy of Dermatology, 45, 68-71. http://dx.doi.org/10.1067/mjd.2001.114588

[6] Eliezri, Y.D., Silverstein, S.J. and Nuovo, G.J. (1990) Occurrence of Human Papillomavirus Type 16 DNA in Cutaneous Squamous and Basal Cell Neoplasms. Journal of the American Academy of Dermatology, 23, 836-842. http://dx.doi.org/10.1016/0190-9622(90)70299-W

[7] Mulayim, N., Silver, D.F. and Ocar, I.T. (2002) Vulvar Vassal Cell Carcinoma: Two Unusual Presentations and Review of the Literature. Gynecologic Oncology, 85, 532-537. http://dx.doi.org/10.1006/gyno.2001.6582

[8] Bunker, C.B. and Neill, S.M. (2004) The Genital, Perianal and Umbilical Regions. In: Burns, T., Breathnach, S., Cox, N. and Griffiths, C., Eds., Textbook of Dermatology, 7th Edition, Blackwell Science, Oxford, 68.1-68.104. http://dx.doi.org/10.1002/9780470750520.ch68

[9] Suarez-Amor, O., Monteagudo, B. and Cabanillas, M. (2009) Vulval Location: An Indication for Staging in Basal Cell Carcinoma? Australasian Journal of Dermatology, 50, 297.

[10] Montegi, S., Tamura, A. and Tanaka, S. (2006) Aggressive Basal Cell Carcinoma with Pulmonary Metastasis. European Journal of Dermatology, 16, 585-586.

\section{Submit or recommend next manuscript to SCIRP and we will provide best service for you:}

Accepting pre-submission inquiries through Email, Facebook, LinkedIn, Twitter, etc.

A wide selection of journals (inclusive of 9 subjects, more than 200 journals)

Providing 24-hour high-quality service

User-friendly online submission system

Fair and swift peer-review system

Efficient typesetting and proofreading procedure

Display of the result of downloads and visits, as well as the number of cited articles

Maximum dissemination of your research work

Submit your manuscript at: http://papersubmission.scirp.org/ 